\title{
Spawanie łukowe stali duplex pod kątem maksymalizacji odporności połączeń spawanych na korozję wżerową w środowisku chlorków
}

\author{
Arc welding of duplex steinless steels considering maximum \\ increase of weld corrosion resistance
}

\section{Streszczenie}

Dwufazowe stale ferrytyczno-austenityczne typu duplex wykazują doskonałą kombinację właściwości mechanicznych i odporności na korozję, w tym szczególnie agresywną korozję wżerową w środowisku chlorkowym. Pomimo wiedzy i doświadczenia zdobytego podczas spawania tych stopów aktualnie nadal obserwuje się problemy ujawniane $w$ trakcie badań korozyjnych. Dobrze uzasadniony termin „dobra spawalność" odnosi się wyłącznie do grupy cech technologicznych ułatwiających łączenie elementów metalowych przez spawanie, ale nie oznacza automatycznie wysokiej odporności na korozję połączeń spawanych, która w środowisku chlorków osiąga tylko $50 \div 80 \%$ materiału rodzimego. W artykule zostały omówione wszystkie czynniki metalurgiczne oraz technologiczne mające wpływ na końcowe właściwości korozyjne złączy spawanych.

Słowa kluczowe: stal duplex, spawanie łukowe, korozja wżerowa

\begin{abstract}
Two-phase ferrite-austenitic duplex stainless steels demonstrate excellent combination of strength and corrosion resistance including particularly aggressive pitting corrosion in chloride environment. The use of duplex and super-duplex stainless steels has continued to increase since last decade of XX century but despite of the knowledge and experience acquired there are still problems encountered in practice. Well justified term "good weldability" refers exclusively to the group of technological features for easy metal parts joining by welding, but not to the automatic provision of corrosion resistance of welding joints, which in chlorides environment reaches only $50 \div 80 \%$ of original parent material resistance. Welding technology factors and impact on final corrosion resistance of welds are widely discussed. This includes particularly weld chemical composition, heat input balance, oxidation, nitrogen content, shielding and purging gas, and the practical constraints of the welding process.
\end{abstract}

Keywords: duplex steel, arc welding, pitting corrosion

\begin{abstract}
Wstęp
Dwufazowe ferrytyczno-austenityczne stale nierdzewne duplex cechuje relatywnie wysoka na tle innych grup stali odporność na różne formy korozji, w tym szczególnie agresywną korozję wżerową w środowisku chlorków (ang. pitting). Wysokie właściwości wytrzymałościowe pozwalają na redukcję masy obiektów, co przy dużej plastyczności znacznie ogranicza ryzyko katastroficznego pękania. Z tych względów stale te pomimo znacznej ceny znajdują coraz szersze i ekonomicznie uzasadnione obszary zastosowania w różnych gałęziach przemysłu. Impulsem do rozwoju nowych gatunków stali duplex stało się rosnące zapotrzebowanie na instalacje platform wiertniczych i tankowców do transportu ropy naftowej, związane z jej wydobyciem spod dna morskiego. Pełne wykorzystanie potencjału stali
\end{abstract}

duplex wymaga jednak ze strony spawalników przemyślanych działań opartych o rzetelną wiedzę inżynierską. Dominujące $\mathrm{w}$ praktyce, rutynowe podejście do opracowania technologii spawania zapewnia uzyskanie wymaganych właściwości mechanicznych złącza spawanego stali duplex, nie mniej nie gwarantuje oczekiwanej odporności korozyjnej, która w środowisku chlorków osiąga zaledwie 50 $\div 80 \%$ odporności materiału podstawowego.

\section{Ogólna charakterystyka stali duplex}

Typową mikrostrukturę prawidłowo zbalansowanej stali duplex przedstawiono na rysunku 1.

Mgr inż. Marek Stankiewicz - Politechnika Krakowska, dr inż. Benedykt Ślązak - Politechnika Częstochowska.

Autor korespondencyjny/Corresponding author: bslazak@eagle.org 


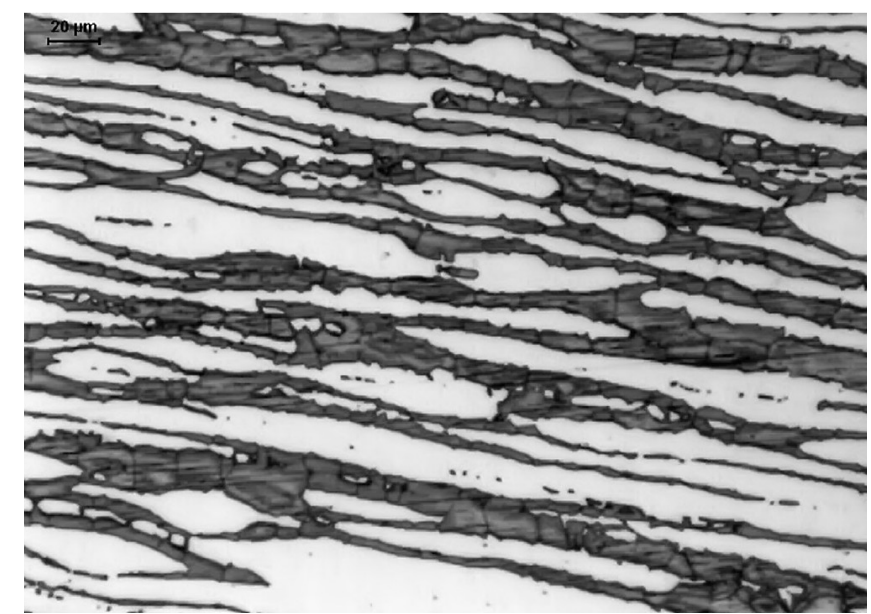

Rys. 1. Poprawna struktura stali duplex z ok. $50 \%$ udziałem ferrytu (obszary ciemne)

Fig. 1. Properly balanced duplex stainless steel microstructure with approx. 50\% ferrite content (dark zones). Photo by authors

Ciemne, wytrawione przez odczynnik pola to ferryt, pola jasne to austenit. Na rysunku 2 zilustrowano natomiast aktualny podział stali duplex oraz ich zalety i ograniczenia.

$\mathrm{Na}$ rysunku $3 \mathrm{a}$ zaprezentowano podział stali duplex na 5 kategorii:

1. Lean Duplex - LDSS;

2. Standard Duplex o zawartości $22 \% \mathrm{Cr}$ - DSS $22 \% \mathrm{Cr}$;

3. High Alloyed Standard Duplex o zawartości $25 \% \mathrm{Cr}$ - DSS $25 \% \mathrm{Cr}$;

4. Super Duplex - SDSS

5. Hyper Duplex - HDSS,

oraz typową zawartość najważniejszych składników stopowych występujących w tych stalach: $\mathrm{Cr}, \mathrm{Mo}, \mathrm{Ni}, \mathrm{Mn}, \mathrm{Cu}$ i N.

Zbalansowane stale duplex lokują się na wykresie Schaefflera-DeLonga teoretycznie na linii 50\% zawartości ferrytu (rys. 3b). W praktyce, w poprawnie zbalansowanej stali proporcje ferrytu do austenitu kształtują się w szerszych granicach

$$
\frac{\text { ferryt }}{\text { austenit }} \approx \frac{50 \%^{-10 \%}}{50 \%^{+10 \%}}
$$
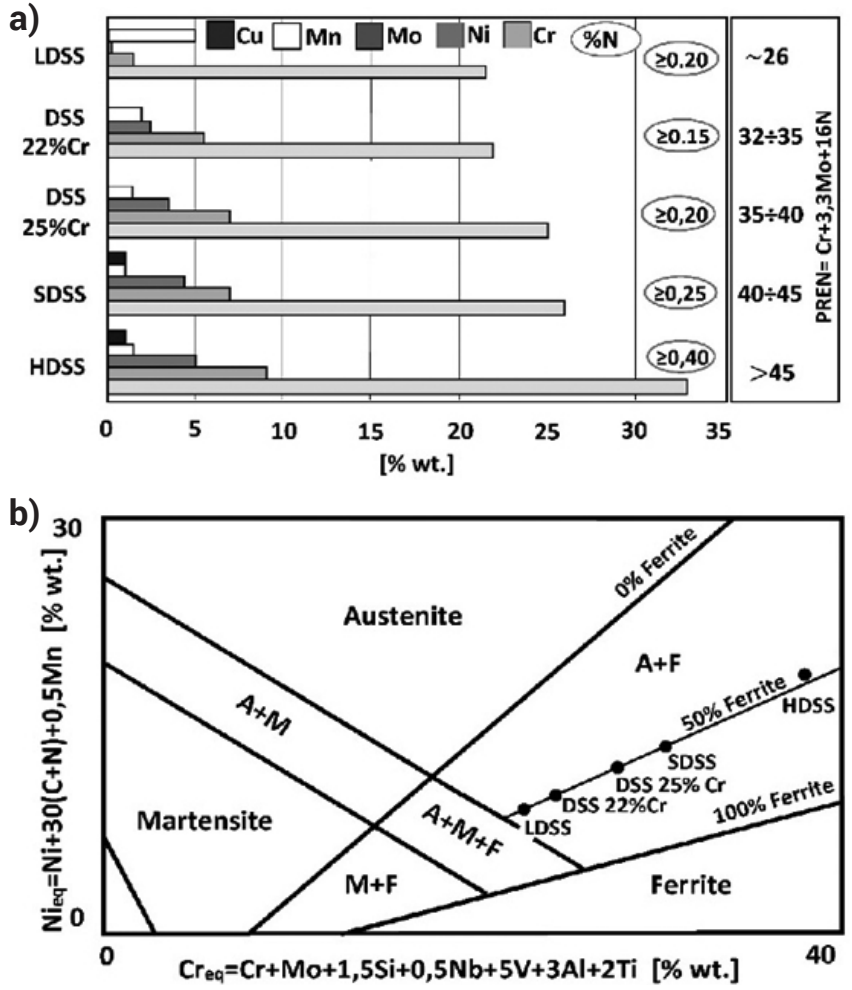

Rys. 3. Stale wysokostopowe typu duplex [1]: a) typowy skład chemiczny oraz wskaźnik PRE, b) poszczególne grupy stali duplex na wykresie duplex Schaeffler-DeLong'a

Fig. 3. Duplex Stainless Steel [1]: a) typical chemical composition and PRE number, b) alloys on the Schaeffler-DeLong diagram

\begin{tabular}{|c|c|c|c|}
\hline \multicolumn{4}{|c|}{ Duplex Stainless Steels: two-phase microstructure approx. 50\% ferrite / 50\% austenite } \\
\hline Classification & \multicolumn{2}{|c|}{ Advantages } & Limitations \\
\hline $\begin{array}{l}\text { Lean Duplex (LDSS): } \\
\text { low Ni and Mo. }\end{array}$ & \multirow{3}{*}{$\begin{array}{l}\text { Twice higher yield strength } \\
\text { than typical } 18 / 8 \text { austenitic } \\
\text { steel along with fair } \\
\text { elongation } A_{5}>25 \% \text {. }\end{array}$} & $\begin{array}{c}\text { Reduced risk of } \\
\text { intergranular attack. }\end{array}$ & $\begin{array}{c}\text { Special metallurgical } \\
\text { technologies for enhancing } \\
\text { nitrogen content. }\end{array}$ \\
\hline in chloride environment. & & \multirow{3}{*}{$\begin{array}{l}\text { Higher thermal conductivity, } \\
\text { lower thermal expansion } \\
\text { vs. } 18 / 8 \text { austenitic steels. }\end{array}$} & \multirow{3}{*}{$\begin{array}{l}\text { Excessive ferrite content } \\
\text { in the weld metal or } H A Z \text {. }\end{array}$} \\
\hline & & & \\
\hline Duplex (DSS) & \multirow{2}{*}{$\begin{array}{c}\text { Good material for thin- } \\
\text { walled structures, marine, } \\
\text { offshore, bridges, etc. }\end{array}$} & & \\
\hline $\begin{array}{l}\text { - Standard } 22 \% \mathrm{Cr} \text { (DSS 22\%Cr); } \\
\text { - High alloyed } 25 \% \mathrm{Cr} \text { (DSS 25\%Cr): }\end{array}$ & & \multirow{2}{*}{$\begin{array}{l}\text { Good weldability. } \\
\text { Welded joints resistant } \\
\text { to hot cracking. }\end{array}$} & \multirow{2}{*}{$\begin{array}{l}\text { Prone to formation harmful } \\
\text { intermetallic phases } \sigma, X \\
\text { and brittleness } 475^{\circ} \mathrm{C} \text {. }\end{array}$} \\
\hline $\begin{array}{l}\text { good corrosion resistance } \\
\text { in chloride environment }\end{array}$ & \multirow{2}{*}{$\begin{array}{l}\text { High resistance to pitting, } \\
\text { crevice corrosion } \\
\text { and stress corrosion } \\
\text { in chloride environment } \\
\text { (except LDSS). }\end{array}$} & & \\
\hline $\begin{array}{l}\text { at room temperature. } \\
\text { Most widely used from all duplex } \\
\text { stainless steels. }\end{array}$ & & \multirow[t]{2}{*}{$\begin{array}{l}\text { Good resistance to abrasive } \\
\text { wear and erosion. }\end{array}$} & $\begin{array}{c}\text { Lower corrosion resistance } \\
\text { of welds than the parent } \\
\text { metal. }\end{array}$ \\
\hline $\begin{array}{c}\text { Superduplex (SDSS); } \\
\text { Hyperduplex (HDSS): } \\
\text { contains Cu. Excellent combination } \\
\text { of strength and corrosion }\end{array}$ & & & $\begin{array}{l}\text { Temperature range of use: } \\
-50^{\circ} \mathrm{C} \text { (ferrite brittleness) } \\
\quad \div \\
\sim 280^{\circ} \mathrm{C} \text { (brittleness } 475^{\circ} \mathrm{C} \text { ) }\end{array}$ \\
\hline
\end{tabular}


W prawej części rysunku 3a podano wielkość wskaźnika PREN - Pitting Resistance Equivalent Number - służącego do teoretycznego oszacowania odporności na korozję wżerową w środowisku chlorków. Wskaźnik PREN dotyczy zasadniczo stali termodynamicznie stabilnych, a więc po końcowej obróbce cieplnej. W przypadku stali duplex do obliczania wielkości PREN znajdują zastosowanie następujące formuly $[1,2,3]$ :

- Herbsleba: PREN $=\mathrm{Cr}+3,3 \mathrm{Mo}+16 \mathrm{~N}$

oraz dla stali SDSS i HDSS zawierających W lub Cu:

- Okamoto: $\quad \mathrm{PREN}_{\mathrm{W}}=\mathrm{Cr}+3,3(\mathrm{Mo}+0,5 \mathrm{~W})+16 \mathrm{~N}$

- Heimgartnera: PREN $\mathrm{Cu}_{\mathrm{Cu}}=\mathrm{Cr}+3,3 \mathrm{Mo}+15 \mathrm{~N}+2 \mathrm{Cu}$

- formuła rozszerzona:

gdzie:

PREN $_{\mathrm{EXT}}=\mathrm{Cr}+3,3(\mathrm{Mo}+0,5 \mathrm{~W})+2 \mathrm{Cu}+16 \mathrm{~N}(4)$

Cr...N - zawartość składnika stopowego w stali w procentach wagowych [\%wt].

Wskaźnik PREN przyjmuje wartości od ok. 26 dla stali LDSS o przeciętnej odporności na korozję wżerową w chlorkach, do ponad 45 dla stali HDSS o wysokiej odporności. Przydatność wskaźnika PREN do szacowania odporności materiałów spawalniczych jest ograniczona. Określenie „wysoka odporność korozyjna" ma charakter relatywny, z tego względu wielkości wskaźnika PREN należy traktować tylko jako dane porównawcze, a o ostatecznym doborze stali powinny zadecydować badania w konkretnym medium korozyjnym i temperaturze.

\section{Metalurgia stali duplex i jej połączeń spawanych}

Stale duplex krystalizują z fazy ciekłej na ogół w postaci ferrytu $\delta$. W trakcie chłodzenia stopu wskutek zmniejszania parametru sieci A2 rosną jej naprężenia spowodowane hamowaniem skurczu przez pierwiastki o większym promieniu atomowym niż Fe, np. Ni. W miejscach o podwyższonej koncentracji pierwiastków austenitotwórczych z chwilą osiągnięcia temperatury $\delta$ solvus sieć ferrytu $A 2$ ulega transformacji do sieci A1, o większym o $25 \%$ parametrze sieciowym - rysunek 4a - czemu towarzyszy spadek naprężeń, a tym samym energii granic międzyziarnowych. Jest to czynnik napędowy przemiany $\delta \rightarrow \delta+\gamma$. Stosownie do wielkości współczynników rozdziału pierwiastków stopowych $K_{\delta / y}$ oraz ich granicznej rozpuszczalności w ferrycie i austenicie - rysunki 4b, 4c, tablica I - następuje wzrost koncentracji

Tablica I. Maksymalna rozpuszczalność pierwiastków stopowych Table I. Maximum solubility of alloying elements

\begin{tabular}{|c|c|c|c|}
\hline \multirow{2}{*}{ Element } & \multirow{2}{*}{ Lattice structure } & \multicolumn{2}{|c|}{ Solubility [\% wt.] } \\
\cline { 3 - 4 } & & Ferrite & Austenite \\
\hline W & A2 & 35 & 4,7 \\
\hline Mo & A2 & 31 & 1,7 \\
\hline $\mathrm{Mn}$ & $\mathrm{A} 1$ & 3,5 & 100 \\
\hline $\mathrm{Cr}$ & $\mathrm{A} 2$ & 100 & 12,5 \\
\hline $\mathrm{Cu}$ & $\mathrm{A} 1$ & 2,1 & 12 \\
\hline $\mathrm{Ni}$ & $\mathrm{A} 1$ & 6 & 100 \\
\hline $\mathrm{Si}$ & $\mathrm{A} 4$ & 11 & 1,7 \\
\hline $\mathrm{C}$ & - & 0,03 & 2,1 \\
\hline $\mathrm{N}$ & - & 0,1 & 2,8 \\
\hline
\end{tabular}

Cr, Si, Mo, W, P w sieci A2 ferrytu oraz Ni, N, Cu, Mn, C w sieci A1 austenitu. Przemiana ma charakter dyfuzji bliskiego zasięgu, w konsekwencji czego powstający austenit przybiera postać lamelarną (wyspową). Z jednorodnego ferrytu $\delta$ powstaje struktura dwufazowa $\delta+\gamma$, której składniki różnią się pomiędzy sobą także odpornością korozyjną. W ferrycie koncentrują się Cr i Mo, silnie podnoszące potencjał elektrochemiczny, a tym samym odporność korozyjną. W austenicie tylko azot $\mathrm{N}$ rozpuszczony $\mathrm{w}$ formie roztworu międzywęzłowego istotnie zwiększa potencjał elektrochemiczny stali - rysunki 4c, $4 d$.

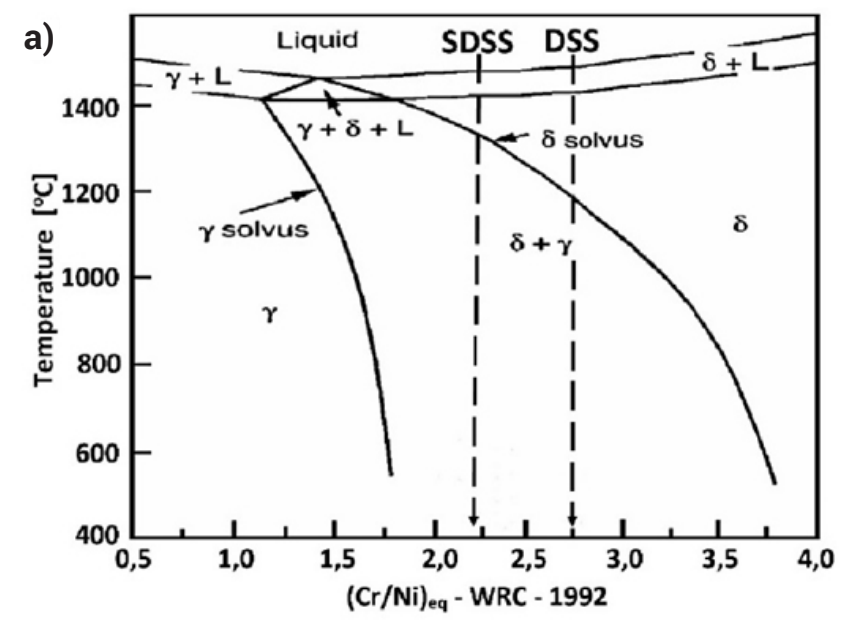

Ferrite (A2)

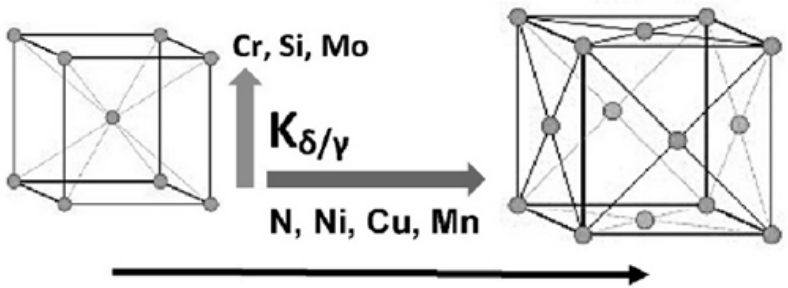

Increase solubility of alloying elements. Decrease diffusion rate.

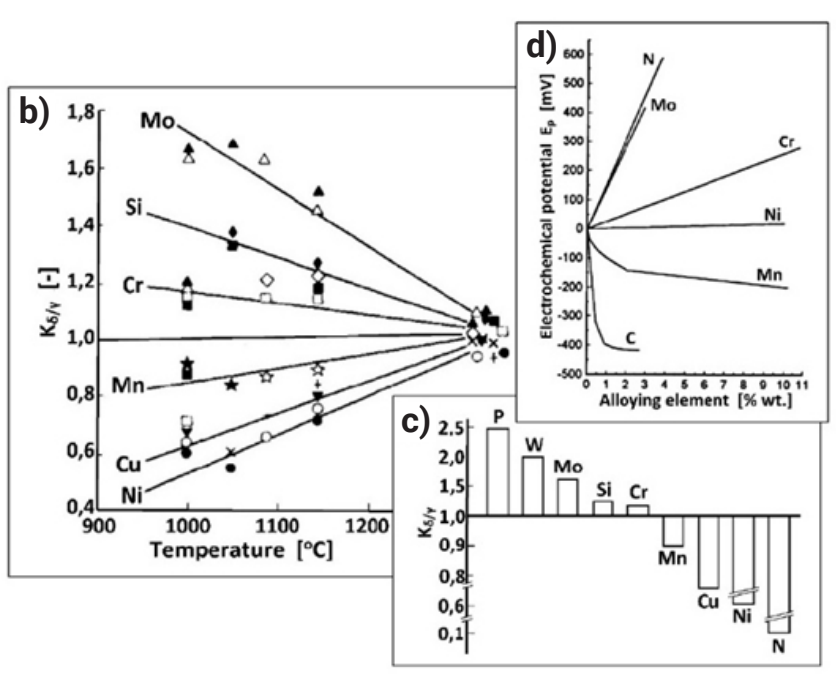

Rys. 4. a) Wykres fazowy stali duplex wraz z przemianą austynityczną $\delta \rightarrow \delta+\gamma[6], b)$ współczynnik rozdziału pierwiastków stopowych $\left.\mathrm{K}_{\delta / y}[7], c\right)$ typowe wartości współczynników rozdziału $\mathrm{K}_{\delta / y}$ dla stali duplex [6], d) wpływ pierwiastków stopowych na potencjał elektrochemiczny dla stali typu 304 [8]

Fig. 4. a) Duplex stainless steel phase diagram and the austenite $\delta \rightarrow \delta+\gamma$ transition [6], b) element partitioning coefficients $K_{\delta / y}$ for a range of duplex stainless steel [7], c) typical partition coefficients $K_{\delta / y}$ for duplex stainless steel [6], d) the influence of alloying elements on the electrochemical potential for 304 stainless steel [8] 
Zasadniczo Mn i Ni obniżają tą odporność, jednak z uwagi na umacniające działanie Mn na wytrzymałość stali oraz niezbędny dodatek Ni dla zainicjowania dekompozycji ferrytu i powstania struktury dwufazowej z udziałem austenitu pierwiastki te są stałym komponentem stali duplex.

Proces dekompozycji ferrytu $\delta$ i formowania struktury dwufazowej $\delta+\gamma$ przebiega $w$ temperaturze $1200 \div 800{ }^{\circ} \mathrm{C}$. Ze względu na jego dyfuzyjny charakter kinetyka i konsekwencje przemiany są zależne od czasu stygnięcia stali w tym zakresie temperatury $\Delta \mathrm{t}_{12 / 8}$ - rysunek 5 .

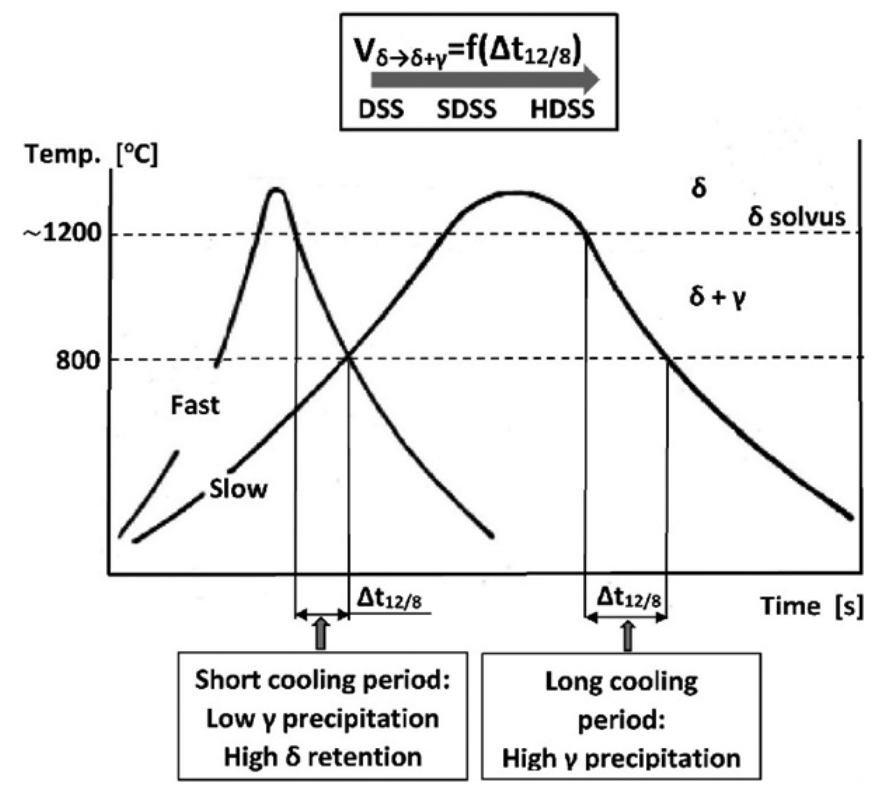

Rys. 5. Wpływ szybkości chłodzenia na zawartość ferrytu [7] Fig. 5. Effect of cooling rate on ferrite content [7]

Wolne chłodzenie powoduje powstanie austenitu y w ilości bliskiej stanowi równowagi termodynamicznej, a rozdział pierwiastków stopowych pomiędzy składniki osnowy jest również bliski równowagowemu. Szybkie chłodzenie powoduje powstanie struktury metastabilnej, o mniejszej zawartości austenitu. Dla uzyskania w końcowej mikrostrukturze wyższej zawartości austenitu y pożądane jest wolne stygnięcie w zakresie temperatury formowania struktury dwufazowej $\delta+\gamma$, co może zapewnić odpowiednio wysoka energia liniowa spawania. W niższej temperaturze stygnięcia, poniżej $1050{ }^{\circ} \mathrm{C}$ sytuacja ulega odwróceniu - w celu przeciwdziałania dużej skłonności do wydzielania się szkodliwych wtórnych faz międzymetalicznych zdecydowanie pożądana staje się większa szybkość stygnięcia, tak aby linia stygnięcia nie przecięła górnej krzywej CTP początku wydzielania tych faz (rys. 6). Wydzielanie w stalach duplex twardych i kruchych, a przez to szkodliwych faz wtórnych zachodzi w dwóch przedziałach temperatury, co schematycznie obrazują krzywe CTP na rysunku 6. Górna krzywa odpowiadająca zakresowi $1050 \div 600{ }^{\circ} \mathrm{C}$ przedstawia początek wydzielania azotków, węglików i faz międzymetalicznych wskutek zbyt długiej ekspozycji cieplnej stali w tym zakresie temperatury, np. niedostatecznie szybkiego studzenia poniżej temperatury $1050^{\circ} \mathrm{C}$. Zatem spawając wysokimi energiami liniowymi ułatwiamy przemianę $\delta \rightarrow \delta+\gamma$, co jest efektem korzystnym, a z drugiej strony również zwiększamy prawdopodobieństwo wydzielenia faz wtórnych w obrębie ferrytu przy niedostatecznie szybkim studzeniu, co jest rezultatem niepożądanym. Konsekwencją tego jest konieczność ścisłego przestrzegania zalecanych energii liniowych spawania, a tym samym kontroli szybkości stygnięcia złącza.

Dolna krzywa CTP odpowiadająca temperaturze $550 \div 300{ }^{\circ} \mathrm{C}$ ilustruje początek pozostałych zmian wtórnych w mikrostrukturze, z których najważniejszą rolę odgrywa

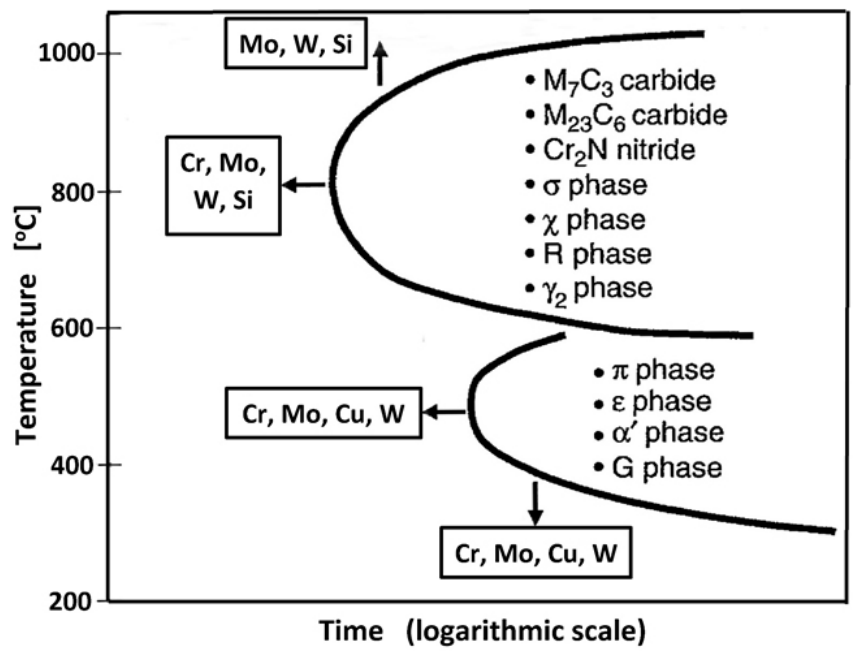

Rys. 6. Uproszczony wykres CTP Czas-Temperatura-Przemiana dla stali duplex [8]

Fig. 6. Time-Temperature-Transition TTT diagram for duplex stainless steel [8]

zmiana formy wydzieleń części ferrytu $\delta$ do postaci iglastego ferrytu wtórnego a', odpowiadająca za tzw. kruchość $475^{\circ} \mathrm{C}$ znacznie obniżającą ciągliwość i udarność stali. Dolna granica występowania niekorzystnego ferrytu a' wyznacza najwyższą temperaturę długoterminowej ekspozycji cieplnej, a więc maksymalną temperaturę stosowania stali duplex, która wynosi ok. $300^{\circ} \mathrm{C}$.

Zaawansowanie szkodliwych zmian w mikrostrukturze obniżających plastyczność i odporność korozyjną stali duplex, czego przykładem są rysunki 7a i 7b, uzależnione jest od czasu sumarycznej ekspozycji cieplnej stali na oba krytyczne zakresy wyznaczone przez krzywe CTP. Ekspozycja najniżej stopowej stali LDSS na temperaturę pomiędzy $1000 \div 800{ }^{\circ} \mathrm{C}$ bez wydzielenia szkodliwych faz może przekraczać nawet 10 godzin. Czas ten dla standardowej stali DSS $22 \%$ Cr skraca się do ok. 30 $\div 60$ minut, a dla stali HDSS do ok. $5 \div 10$ minut [10]. Obecność na granicach ferrytu $\delta$ dopuszczalnej zawartości 0,5\% faz wtórnych wywołuje dramatyczny spadek pracy łamania KV (rys. 7).

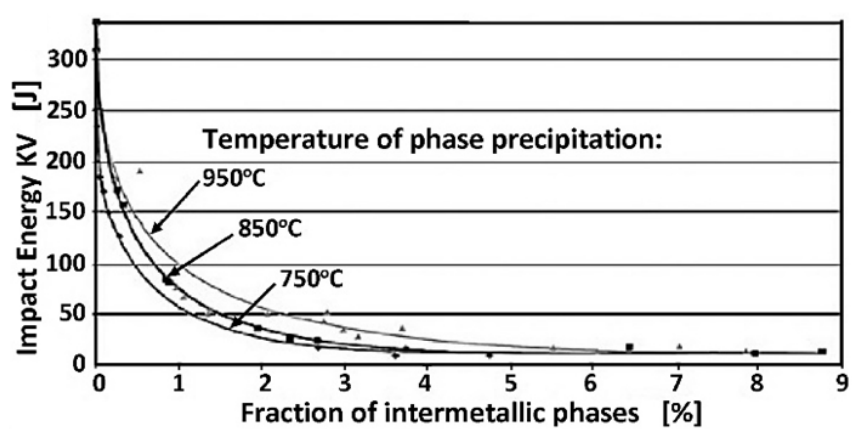

Rys. 7. Udarność KV w zależności od ilości kruchych wtrąceń niemetalicznych [9]

Fig. 7. Impact energy vs. percentage of intermetallic phases [9]

Azot w stali duplex bardzo silnie i korzystnie wpływa na kinetykę formowania austenitu (rys. 8). Ze wzrostem zawartości azotu następuje rozszerzenie obszaru równowagi wysokotemperaturowej $\delta+\gamma$ w kierunku niższych zawartości Ni oraz podniesienie temperatury początku formowania austenitu (nawet do temperatury T liquidus, co oznacza krystalizację niewielkiej części austenitu bezpośrednio z ciekłego metalu) oraz znaczne zwiększenie prędkości przemiany $\delta \rightarrow \delta+\gamma$. $Z$ tego powodu stale bogate $w$ azot można chłodzić w zakresie temperatury $1200 \div 800{ }^{\circ} \mathrm{C}$ szybciej bez obawy o przekroczenie końcowej zawartości ferrytu powyżej dopuszczalnego poziomu $70 \%$. Dodatek $\mathrm{N}_{2}$ do gazu 


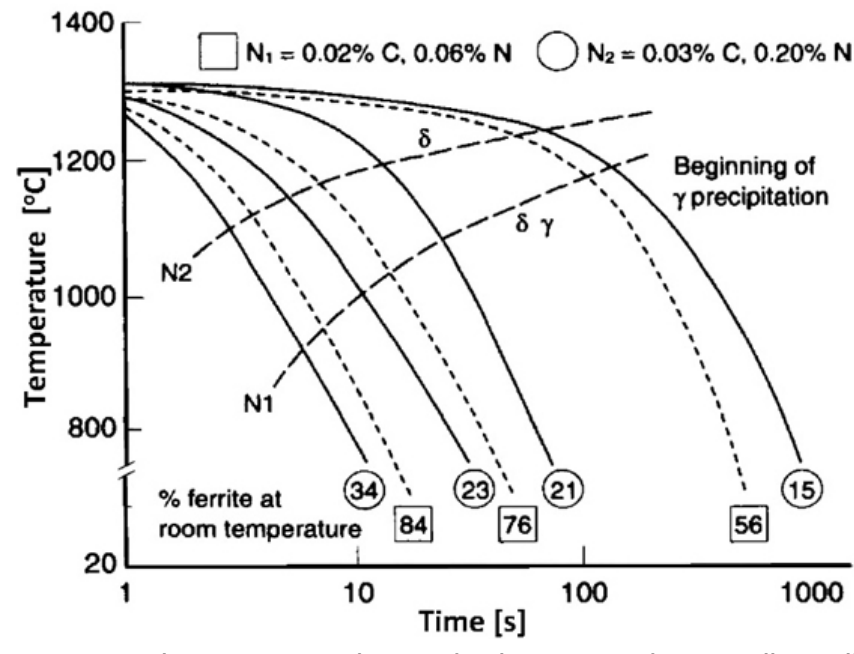

Rys. 8. Wykres CTP w zależności od zawartości azotu dla stali Super Duplex 25\%Cr [5]

Fig. 8. TTT diagrams for different nitrogen contents in DSS $25 \% \mathrm{Cr}$ [5]

formującego i osłonowego przy spawaniu metodą GTAW (TIG, 141) ma fundamentalne znaczenie dla uzyskania prawidłowo zbalansowanej mikrostruktury spoiny.

Objętościowy udział ferrytu \%ठ w mikrostrukturze po końcowej obróbce cieplnej można zweryfikować doświadczalnie przez badania mikroskopowe na drodze analizy obrazowej lub metodami magnetycznymi np. za pomocą ferrytoskopu. Wskazania wielkości liczby ferrytowej FN przelicza się w przypadku stali duplex na objętościowy udział ferrytu $\delta$ z następującej zależności [11]:

$$
\% \delta=0,7 \mathrm{FN}
$$

gdzie:

$\% \delta$ - objętościowy udział ferrytu $\delta$ w mikrostrukturze [\%];

FN - określona w drodze pomiarów liczba ferrytowa.

W przypadku braku możliwości wykonania badań można dokonać oszacowania objętościowego udziału ferrytu \%ठ w stali duplex, posługując się danymi z atestów hutniczych oraz poniższą zależnością [10]:

$$
\begin{aligned}
& \% \delta=4,01 \mathrm{Cr}_{\text {eq }}-5,6 \mathrm{Ni}_{\text {eq }}+0,016 \mathrm{~T}-20,93 \text { [\% wt.] } \\
& \mathrm{Cr}_{\text {eq }}=\mathrm{Cr}+1,73 \mathrm{Si}+0,88 \mathrm{Mo}[\% \mathrm{wt} .] \\
& \mathrm{Ni}_{\text {eq }}=\mathrm{Ni}+24,55 \mathrm{C}+21,75 \mathrm{~N}+0,4 \mathrm{Cu}[\% \mathrm{wt} .]
\end{aligned}
$$

gdzie:

T - temp. wyżarzania homogenizującego $\left(1050 \div 1150{ }^{\circ} \mathrm{C}\right)$; Cr...Cu - zawartość w stali odpowiedniego pierwiastka stopowego w [\% wt].

Obszarem spoiny najbardziej narażonym na obniżenie odporności na korozję wżerową jest strefa wpływu ciepła SWC. Szczególne zagrożenie dla materiału SWC stwarza czas oddziaływania w pobliżu linii wtopienia temperatury przekraczającej poziom $\delta$ solvus, kiedy mikrostruktura stali duplex ma charakter jednofazowy i brakuje czynnika hamującego swobodny rozrost ziaren ferrytu $\delta$. Ponowne obniżenie temperatury poniżej poziomu $\delta$ solvus $w$ trakcie stygnięcia złącza aktywuje dekompozycję ferrytu $\delta \rightarrow \delta+\gamma$. Kumulujący się efekt cykli cieplnych spawania kolejnych ściegów prowadzi w konsekwencji do wzrostu zawartości ferrytu w SWC kosztem zawartości austenitu i zwiększonej skłonności do wydzielania z ferrytu faz wtórnych, a tym samym do obniżenia zarówno plastyczności, jak i odporności na korozję wżerową strefy wpływu ciepła. Podwyższona w stosunku do materiału rodzimego zawartość austenitotwórczego Ni w spoinie oraz absorbcja silnie austenitotwórczego azotu z gazu formującego i osłonowego intensyfikują kinetykę przemiany $\delta \rightarrow \bar{\delta}+\gamma$, przeciwdziałając obniżaniu zawartości austenitu w mikrostrukturze spoiny.
Korozja wżerowa stali jest procesem elektrochemicznym zachodzącym w elektrolitach, zwłaszcza wodnych roztworach soli o niskim $\mathrm{pH}$, z których najbardziej agresywnym jest roztwór $\mathrm{FeCl}_{3}$. Atakuje miejscowo i bardzo szybko perforuje metal na wskroś, powodując utratę szczelności. Jest najgroźniejszą formą korozji występującą w instalacjach chemicznych. W początkowym stadium pitting ma charakter korozji międzykrystalicznej [12]. Zbalansowanie stali duplex w granicach $50 / 50 \%$ ogranicza skłonność do wydzielania na granicach międzyziarnowych szkodliwych wydzieleń węglików i azotków, zmniejszając zagrożenie rozwoju korozji międzykrystalicznej w stali duplex.

Fundamentem ochrony korozyjnej stali nierdzewnych Cr-Ni jest trwała i szczelna warstwa pasywna. Obojętna chemicznie wobec agresywnego środowiska chroni aktywną chemicznie stal, zawsze reagującą $\mathrm{w}$ bezpośrednim kontakcie z mediami korozyjnymi. Warstwa pasywna w środowisku utleniającym powstaje samorzutnie, osiąga grubość $2 \div 4 \mathrm{~nm}$ i posiada zdolność samoodbudowy, czyli repasywacji. Najważniejszą rolę w jej budowie odgrywa $\mathrm{Cr}$, który tworzy na powierzchni stali kompleksowy tlenek $(\mathrm{Fe}, \mathrm{Cr})_{2} \mathrm{O}_{3}$. Minimalna zawartość $\mathrm{Cr}$ w stalach $\mathrm{Cr}-\mathrm{Ni}$ pasywująca powierzchnię wynosi $10,5 \%$. Im wyższy stechiometryczny udział $\mathrm{Cr}$ w $(\mathrm{Fe}, \mathrm{Cr})_{2} \mathrm{O}_{3}$, tym bardziej szczelna i odporna jest warstwa pasywna. Mo i N wbudowują się w warstwę pasywną w znacznie mniejszej zawartości niż Cr, wykazując jednak silniejsze oddziaływanie antykorozyjne od chromu, stosownie do wielkości ich potencjałów elektrochemicznych (rys. 4d). Molibden w postaci tlenku $\mathrm{MoO}_{2}$ i oksywodorotlenku $\mathrm{MoO}(\mathrm{OH})$. Azot w postaci anionów, które tworzą barierę elektrostatyczną utrudniającą powierzchniową adsorbcję innych jonów ujemnych np. anionów $\mathrm{Cl}^{-}$i zmniejszającą ryzyko inicjacji korozji wżerowej. Synergiczne oddziaływanie Mo i N zwiększa odporność stali duplex na korozję wżerową w większym stopniu, niż wynikający z sumarycznej zawartości obu pierwiastków Mo+N w stopie i wielkości ich potencjałów elektrochemicznych.

Niedobór azotu w warstwie pasywnej stali duplex ogranicza skuteczność mechanizmu ochronnego warstwy pasywnej nad ziarnami austenitu. Rysunek 9 przedstawia wżery powstałe w wypełnieniu spoiny spawanej łukowo metodą GTAW (TIG, 141). Ściegi wypełnienia spawane były bez udziału azotu w gazie osłonowym. Złącze poddano badaniu odporności na pitting w roztworze $\mathrm{FeCl}_{3}$. Analiza rozkładu pierwiastków na fragmencie powierzchni wżeru zaznaczonym białą kreską, wykonana na mikroskopie skaningowym wyposażonym w mikroanalizator rentgenowski, ujawnia zależność pomiędzy rozkładem $\mathrm{Cr}$ w warstwie wierzchniej a zaabsorbowanym z roztworu korozyjnego chlorem $\mathrm{Cl}$ (rys. 9b, 9c).

W miejscach o wysokim stężeniu Cr (warstwa wierzchnia nad ziarnami ferrytu) zawartość zaabsorbowanego na powierzchni $\mathrm{Cl}$ jest niska (pionowe ciągłe linie na rys. 9c). W miejscach o małym stężeniu $\mathrm{Cr}$ (warstwa wierzchnia nad ziarnami austenitu) zawartość zaabsorbowanego $\mathrm{Cl}$ jest na ogół duża (pionowe linie kreskowe na rys. 9c). Wysoka koncentracja zaabsorbowanego Cl występuje w miejscach o największej intensywności korozji.

W omawianym przypadku stopiwa SDSS ubogiego w azot, a więc o niewystarczająco zbalansowanej mikrostrukturze, dominującą formą rozwoju korozji wżerowej jest atak na przypowierzchniowe ziarna austenitu, a następnie ze względu na obecność szkodliwych faz wtórnych przyległe granice międzyziarnowe. W dalszej kolejności roztrawiane są ziarna obu podstawowych faz osnowy metalicznej.

Pomimo różnych właściwości fizyko-chemicznych warstwy pasywnej nad obszarami ferrytu i austenitu oraz różnych mechanizmów ochrony obu faz przed rozwojem zainicjowanej korozji zrównanie odporności korozyjnej ferrytu 
i austenitu wskutek prawidłowego zbalansowania mikrostruktury w nowoczesnych stalach duplex IV generacji ogranicza ryzyko pittingu na rzecz mniej niebezpiecznej korozji równomiernej, której jednym objawem jest stopniowo postępujący w czasie ubytek wagowy stali.

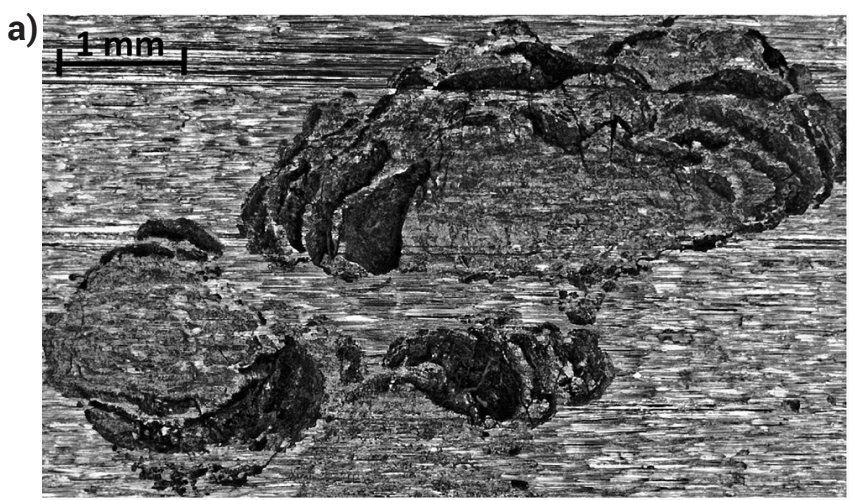

b)

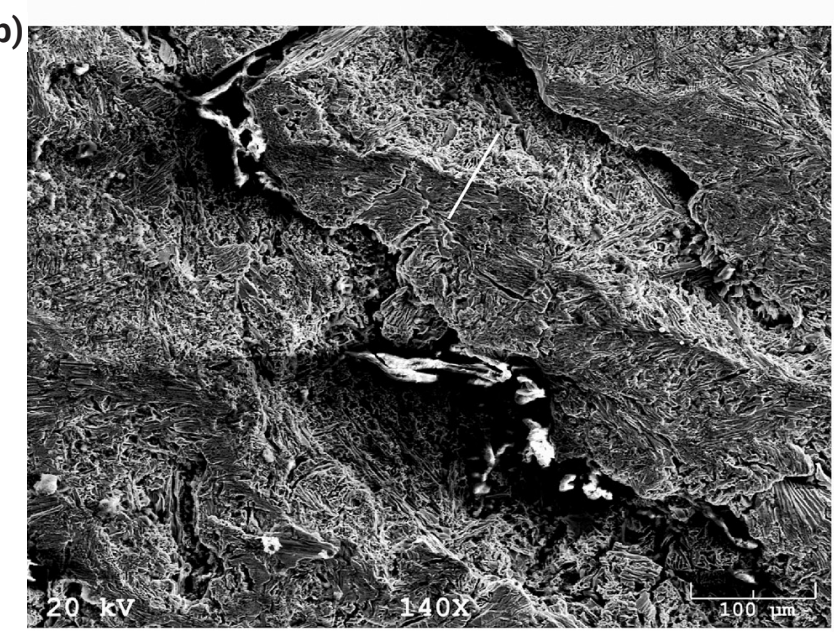

c)

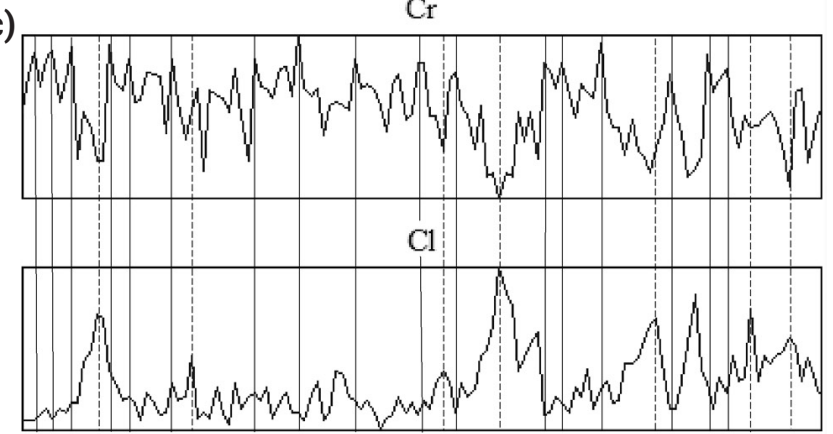

Rys. 9. Wżery w spoinie stali typu SDSS (1.4501, F55). Ściegi wypełniające, GTAW automat. Gaz osłonowy bez zawartości azotu: a) zdjęcie wżeru, b) obraz wżeru z mikroskopu skaningowego, c) zawartość $\mathrm{Cr}$ oraz $\mathrm{Cl}$ wzdłuż linii białej

Fig. 9. Chloride pits in SDSS (1.4501, F55) weld metal. Filling beads, GTAW automatic welding. Shielding gas without $\mathrm{N}_{2}$. a) optical image, b) scanning microscopic image, c) $\mathrm{Cr}$ and $\mathrm{Cl}$ content along a white line

\section{Wpływ technologia spawania na odporność na korozję wżerową stali duplex}

Stali duplex nie należy spawać bez użycia materiału dodatkowego ze względu na ryzyko nadmiernej ferrytyzacji spoiny powstałej wskutek przetopienia materiału rodzimego. Zalecane dla stali duplex stopiwa posiadają zawartość austenitotwórczego Ni wyższą o $2 \div 4 \%$ w stosunku do materiału rodzimego w celu zwiększenia kinetyki formowania austenitu $\delta \rightarrow \delta+\gamma$ i kompensacji braku możliwości późniejszego zbalansowania mikrostruktury elementów spawanych na drodze obróbki cieplnej po spawaniu. Zaleca się spawanie niższych kategorii stali duplex stopiwem o składzie odpowiadającym wyższej kategorii (np. stale DSS spawa się stopiwami o składzie chemicznym stali SDSS) zwłaszcza ściegów graniowych narażonych na bezpośredni kontakt z medium korozyjnym.

Występujący w składzie chemicznym większości gatunków stali duplex azot jest pierwiastkiem silnie zwiększającym kinetykę formowania austenitu. Zależność pomiędzy zawartością azotu i ferrytu $\delta$ a tym samym austenitu w spoinie ma charakter liniowy (rys. 10).

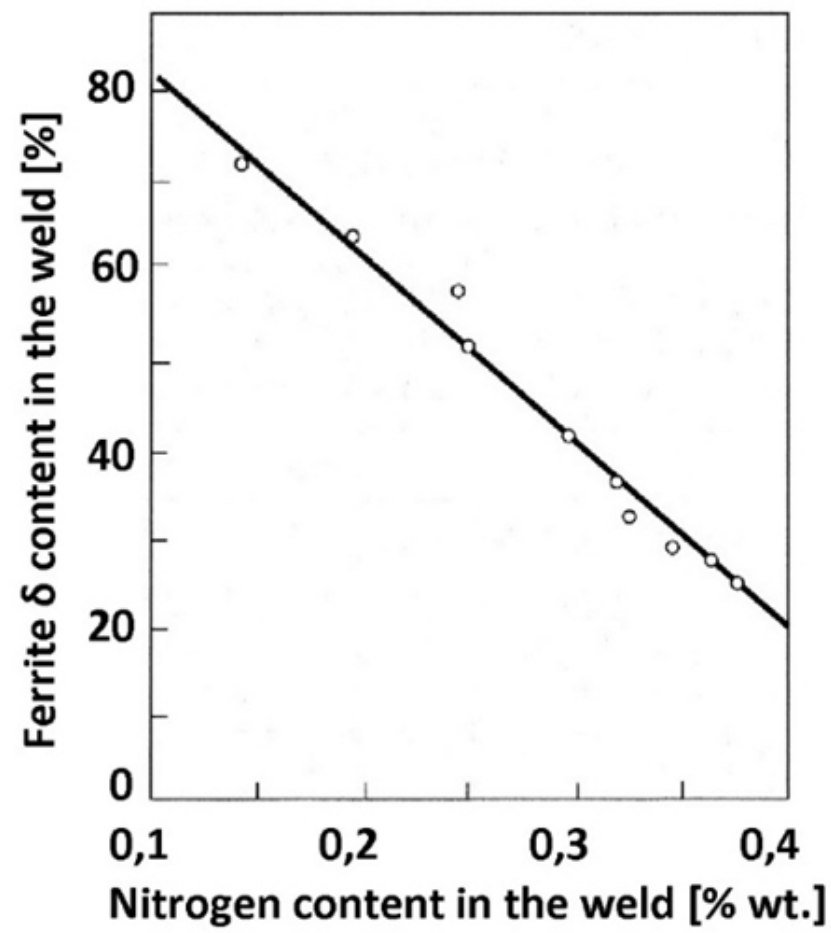

Rys. 10. Wpływ azotu w spoinie na zawartość ferrytu ס, GTAW [19] Fig. 10. Influence of nitrogen content in the weld on the ferrite $\delta$ content, GTAW [19]

Niestety wysoka prężność azotu w temperaturze spawania powoduje jego migrację z jeziorka spawalniczego do otaczającego środowiska, a w konsekwencji zmniejszenia udziału austenitu w strukturze spoiny zwiększenie ryzyka utraty odporności na korozję wżerową i obniżenie udarności KV spoiny. Spoina uboga w azot zawiera nawet $80 \%$ ferrytu $\delta$, spoina bardzo bogata w azot tylko ok. $20 \%$. Ponieważ łuk elektryczny nie przenosi obojętnych elektrycznie atomów azotu, dlatego nie zawierają go materiały dodatkowe do spawania łukowego, a jedyną możliwością uzupełnienia zawartości $\mathrm{N}$ w stopiwie podczas spawania jest dodatek $\mathrm{N}_{2}$ do gazu osłonowego i formującego. Zawartość azotu w gazach osłonowych do spawania metodą GTAW (TIG, 141) powinna mieścić się w zakresie $1 \div 1,2 \%$ dla standardowej stali DSS $22 \%$ oraz $2 \div 2,5 \%$ dla stali DSS $25 \%$, SDSS i HDSS. Najsłabszą przyswajalność azotu obserwujemy w ściegu graniowym. Niedobór azotu w materiale grani spoiny duplex jest główną przyczyną negatywnych rezultatów badania odporności na pitting. Niestety grań spoiny jest najczęściej miejscem o największym zagrożeniu korozją, dlatego niezmiernie ważne jest stosowanie w charakterze gazu formującego mieszanek bogatych w azot. Najwyższą zawartość azotu - nawet do $60 \%$ wyższą niż w ściegu graniowym obserwuje się w ściegach licowych. Stosownie do tego badania mikrostrukturalne spoiny ze stali duplex z określeniem zawartości ferrytu $\delta$ wykonuje się na ogół w grani i ostatnim ściegu lica spoiny, aby uzyskać 
informację o rozpiętości w zawartości ferrytu i tym samym spodziewanej odporności na pitting na obu istotnych powierzchniach złącza spawanego.

Stosowanie gazów osłonowych o zbyt wysokim dodatku azotu grozi przekroczeniem granicznej rozpuszczalności N w roztworze stałym i pojawieniem się zwłaszcza w grubościennych złączach porowatości spoiny. Ponieważ o odporności korozyjnej stali nierdzewnych decydują przede wszystkim właściwości warstwy wierzchniej, dla uniknięcia porowatości można warstwy wypełniające spoin wielościegowych spawać w osłonie czystego Ar bez udziału $\mathrm{N}_{2}$. W takich przypadkach badania korozyjne odporności na pitting nie powinny obejmować wypełnienia spoiny, aby uniknąć sytuacji zilustrowanej na rysunku 9. Dodatek $20 \div 40 \%$ He do gazu osłonowego zwiększa energię cieplną dostarczaną do spoiny, co umożliwia zwiększenie wydajności spawania metodą GTAW.

Pełna kontrola zawartości $\mathrm{O}_{2} \mathrm{~W}$ gazach spawalniczych zapobiega jego absorpcji w jeziorku spawalniczym i szkodliwemu wzrostowi zawartości w roztworze stałym oraz pozwala zmniejszyć grubość warstwy tlenkowej nad złączem spawanym, a przez to głębokość zubożenia warstwy wierzchniej stali w $\mathrm{Cr}$ i Mo. Rekomenduje się stosowanie do stali duplex gazów spawalniczych o zawartości $\mathrm{O}_{2}$ poniżej 200 ppm oraz przepłukiwanie rur od strony grani gazem formującym w celu jak największego obniżenia zawartości $\mathrm{O}_{2}$. Niektóre źródła sugerują nawet bardzo głębokie ograniczenie stężenia $\mathrm{O}_{2}$ poniżej $25 \mathrm{ppm}$.

\section{Rekomendacje technologiczne}

Kosztowne stale duplex z wyjątkiem grupy LDSS stosowane są przede wszystkim ze względu na ich odporność korozyjną w środowisku chlorków. Prawidłowa technologia spawania powinna zapewniać wystarczającą odporność korozyjną co najmniej tych obszarów złączy spawanych, które pozostają w kontakcie $z$ agresywnym medium. W przypadku spawania jednostronnego np. rurociągów i zbiorników jest to grań spoiny z przylegającą strefą wpływu ciepła. Jeżeli tylko jest to możliwe, należy projektować spoiny dwustronne, ponieważ zbalansowanie mikrostruktury i uzyskanie wymaganego poziomu odporności na korozję wżerową ściegów licowych jest zdecydowanie łatwiejsze niż w ściegu graniowym. W złączach jednostronnych z dostępną granią spoiny można stosować podpawanie grani jako sposób na poprawę niskiej odporności korozyjnej tej części złącza. Do każdego ściegu spoiny trzeba precyzyjne i równomierne wprowadzić odpowiednią ilość energii cieplnej, ograniczyć dostęp tlenu, zapewnić niezbędny czas do dekompozycji ferrytu $\delta$ i uformowania optymalnej ilości austenitu y przez odpowiednio wolne studzenie pomiędzy temperaturą $1200{ }^{\circ} \mathrm{C}$ a $1050{ }^{\circ} \mathrm{C}$ oraz zapobiec wydzieleniu szkodliwych faz wtórnych przez szybkie studzenie pomiędzy temperaturą $1050{ }^{\circ} \mathrm{C}$ a $300^{\circ} \mathrm{C}$. Zwłaszcza zakres temperatury stygnięcia od $1050{ }^{\circ} \mathrm{C}$ do $850{ }^{\circ} \mathrm{C}$ wymaga szczególnie intensywnego chłodzenia stali (rys. 11). Kwestią fundamentalną w spawaniu stali duplex

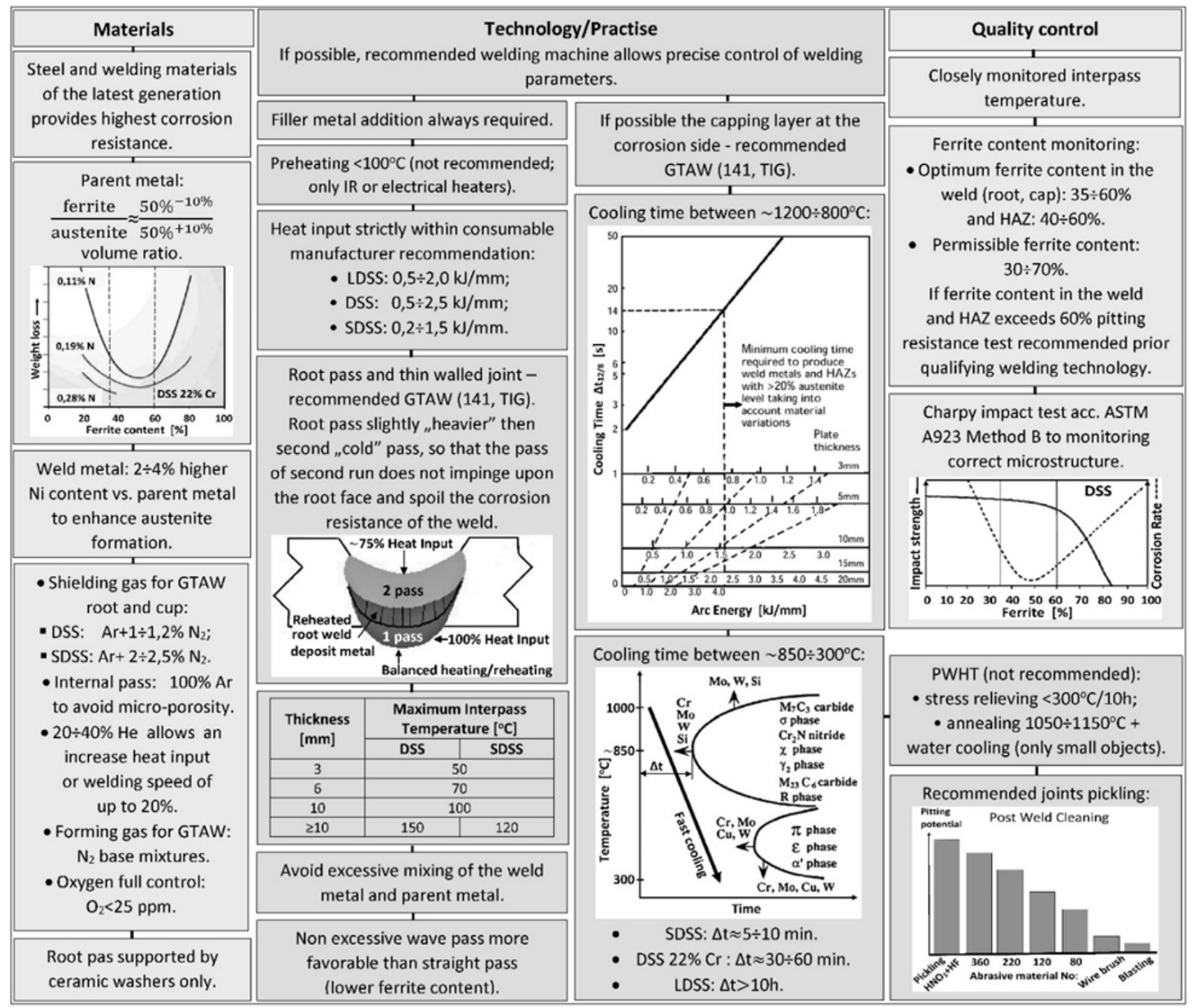

Rys. 11. Wskazówki dotyczące spawanie stali duplex w celu optymalizacji właściwości korozyjnych złącza spawanego [13:18] Fig. 11. Welding good practice scheme enhancing the corrosion resistance of welded duplex stainless steel joints in the chloride environment $[13 \div 18]$ 
klasycznymi metodami łukowymi jest optymalna ilość ciepła wprowadzona do spoiny dla zapewnienia oczekiwanej szybkości stygnięcia powyżej i poniżej temperatury $1050^{\circ} \mathrm{C}$.

Ograniczenie dostępu tlenu do grani spoiny, a nierzadko i lica wymaga stosowania niskotlenowych metod spawania. Na rysunku 12a zilustrowano zależność pomiędzy pracą łamania KV stopiwa, a jego natlenieniem dla klasycznych metod spawania łukowego. Najniższy stopień natlenienia stopiwa osiąga się stosując spawanie metodami GTAW (TIG, 141) oraz będącą jej rozwinięciem metodą PAW (151).

Popularność stosowania i łatwość aplikacji metody GTAW rekomenduje ją do spawania grani, lica, połączeń jednościegowych i cienkościennych ze stali duplex. Alternatywnie, zwłaszcza dla połączeń rurowych, proponowana jest zmodyfikowana metoda GMAW-STT (Surface Tension Trans-

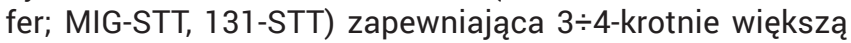
wydajność spawania od GTAW, porównywalną odporność na pitting i zadawalającą plastyczność do temperatury $-40^{\circ} \mathrm{C}[26]$. Stosowanie żużlowych, wysokotlenowych metod spawania łukowego SMAW (111), SAW (121), FCAW (114) nie tylko ogranicza odporność korozyjną spoiny, ale również obniża wielkość pracy łamania KV stopiwa, podnosząc dolną granicę temperatury eksploatacji złączy spawanych (rys. 12b), co jest konsekwencją wysokiej zawartości tlenu atomowego rozpuszczonego w roztworze stałym i obecności wtrąceń tlenkowych na granicach ziaren. Jeżeli wymagania odbiorowe nie narzucają konieczności zapewnienia
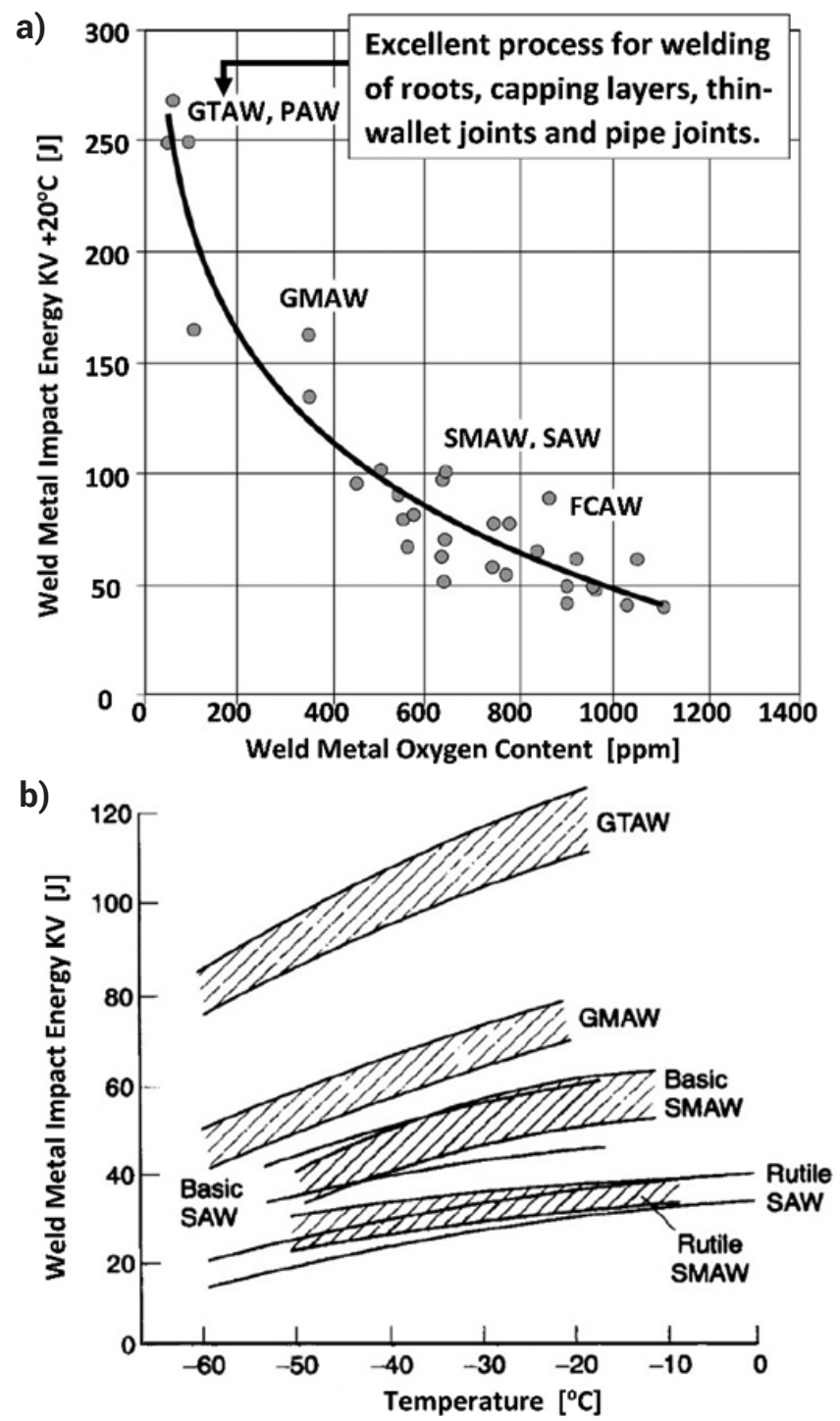

Rys. 12. Wpływ azotu w spoinie na zawartość ferrytu ס, GTAW [19] Fig. 12. Influence of nitrogen content in the weld on the ferrite $\delta$ content, GTAW [19] odporności na pitting wypełnieniu spoiny, ściegi wypełnienia w złączach wielościegowych można spawać dowolną metodą, także wysokotlenową, zapewniającą oczekiwaną wielkość właściwości mechanicznych, a zwłaszcza pracy łamania KV. W złączach spawanych stali o wysokiej granicy plastyczności $R_{0,2}$, jakimi są stale SDSS i HDSS, z uwagi na ich naturalną skłonność do większej kruchości uzyskanie wysokiej udarności KV i niskiej temperatury przejścia w stan kruchy wymaga nie tylko zastosowania na całym przekroju spoiny niskotlenowych metod spawania, ale i precyzyjnego zbalansowania mikrostruktury spoiny oraz SWC.

W stalach duplex istnieje wyraźna zależność pomiędzy wielkością pracy łamania KV, a szybkością korozji wżerowej zilustrowana na rysunku 11 . Wzrost zawartości ferrytu $\delta$ powyżej $50 \%$ powoduje zarówno obniżenie średniej wartości $\mathrm{KV}$, jak i wzrost intensywności korozji wżerowej. O ile wysoka udarność nie zawsze świadczy o dobrej odporności korozyjnej stali duplex, to na ogół niskiej udarności towarzyszy niewystarczająca odporność na korozję wżerową.

Regulacja kinetyki formowania austenitu $y$ w spoinach ze stali duplex poza wspomnianą już podwyższoną zawartością Ni w stopiwie jest możliwa także na drodze odpowiedniego ukształtowania rowka spawalniczego. Kształty rowków są analogiczne jak w przypadku stali austenitycznych kwasoodpornych, jednak optymalne proporcje nieco się różnią. Przykłady i wymiary typowych rowków przy spawaniu stali duplex przedstawiono w publikacji [10]. Rowki do spawania jednostronnego stali duplex charakteryzują się:

- szerszym rozwarciem grani;

- niższym progiem grani;

- większym kątem rozwarcia obszaru wypełnienia i lica spoiny w stosunku do analogicznych rowków dla stali austenitycznych kwasoodpornych [13].

Szersze rozwarcie i niższy próg rowka graniowego ograniczają stopień wymieszania stopiwa z materiałem rodzimym obniżający zawartość Ni w stopiwie grani. Ścieg graniowy powinien być masywny, aby przeciwdziałać niedoborowi azotu na tym etapie spawania przez wydłużenie czasu stygnięcia w zakresie temperatury formowania austenitu. Grań należy spawać stosując wysokie wartości energii liniowej w granicach zalecanych przez wytwórcę stopiwa. Niedogrzanie ściegu graniowego przyspiesza stygnięcie w zakresie temperatury formowania austenitu, nadmierne przegrzanie wydłuża stygnięcie w zakresie temperatury wydzielania szkodliwych faz wtórnych. W obu przypadkach konsekwencją jest obniżenie odporności na korozję wżerową oraz udarności KV. Kolejny, nadgraniowy ścieg w połączeniach wielościegowych stali duplex zwany jest często ściegiem "zimnym”. Należy go spawać przy obniżonej nawet do $75 \%$ wielkości energii liniowej i nie powinien być masywny, aby nie wywołać sięgających bezpośrednio pod warstwę pasywną zmian w mikrostrukturze ściegu graniowego i strefy wpływu ciepła. Efekty cieplne kolejnych warstw spoiny nie mogą w żadnym wypadku wpływać na mikrostrukturę i właściwości ściegu graniowego.

Dodatkowy zabieg wysokotemperaturowej obróbki cieplnej po spawaniu w celu poprawnego zbalansowania mikrostruktury złączy duplex jest możliwy wyłącznie w przypadku małych obiektów, które można poddać w całości wyżarzaniu homogenizującemu w temperaturze $1050 \div 1150^{\circ} \mathrm{C}$, a następnie przesycaniu w wodzie. Lokalna obróbka cieplna z wykorzystaniem mat grzewczych nie może być stosowana z uwagi na degradację mikrostruktury stali na krawędziach mat i brak możliwości szybkiego studzenia. Duże przedmioty można poddać natomiast wyżarzaniu odprężającemu przez ok. 10 godzin w temperaturze nieprzekraczającej $300{ }^{\circ} \mathrm{C}$, aby nie zainicjować przemian mikrostrukturalnych w obrębie niższej krzywej CTP jak na rysunku 6. 
Niezwykle ważnym zabiegiem podnoszącym odporność korozyjną złączy spawanych ze stali duplex jest ich chemiczne wytrawianie w celu usunięcia warstwy tlenkowej powstałej nad spoiną i strefą wpływu ciepła wskutek spawania oraz ponowna pasywacja stali na drodze chemicznej. Warstwa tlenkowa na spoinie i strefie wpływu ciepła jest gruba, nawet do $100 \mathrm{~nm}$ [22], ale wzbogacona w $\mathrm{Fe}_{2} \mathrm{O}_{3}$ (charakterystyczne zabarwienie), dzięki czemu jej odporność na penetrację przez jony $\mathrm{Cl}^{-}$jest obniżona. Duża głębokość zubożenia stali w $\mathrm{Cr}$ i Mo pod warstwą utlenioną ułatwia rozwój zainicjowanej korozji wżerowej. Chemicznie utworzona warstwa pasywna jest bardziej szczelna, koncentracja $\mathrm{Cr}_{2} \mathrm{O}_{3}, \mathrm{MoO}_{2}$ i $\mathrm{MoO}(\mathrm{OH})$ podnoszących potencjał elektrochemiczny jest wyższa, a zasięg obszaru zubożenia w Cr i Mo dużo mniejszy. Zabieg wykonuje się za pomocą roztworów lub past na bazie silnie utleniającego kwasu azotowego $\mathrm{HNO}_{3}$, fluorowodoru $\mathrm{HF}$, a często także perhydrolu $\mathrm{H}_{2} \mathrm{O}_{2}$. Jak pokazano to na rysunku 11 ten sposób oczyszczania złączy spawanych ze stali duplex przynosi najlepsze rezultaty w postaci wzrostu odporności korozyjnej.
Zapewnienie odporności korozyjnej połączeń spawanych stali duplex wymaga rozszerzenia rutynowych czynności kontroli jakości o kilka dodatkowych elementów. Pierwszym jest konieczność kontroli zawartości $\mathrm{O}_{2} \mathrm{~W}$ gazach spawalniczych pomimo stosowania atestowanych mieszanek gazowych od sprawdzonego dostawcy. Dotyczy to zwłaszcza spawania grani, aby w żadnym razie nie został przekroczony poziom dopuszczalny 200 ppm. Drugim elementem jest konieczność ciągłego i dokładnego monitorowania temperatury międzyściegowej.

W stalach duplex jest ona niższa niż w pozostałych grupach stali. Nawyk spawania innych grup stali przy wyższych temperaturach międzyściegowych może doprowadzić do jej odruchowego podwyższenia przez spawacza, a w konsekwencji do wydzielenia szkodliwych faz wtórnych. Są one nieusuwalne w większych gabarytowo obiektach, których nie można poddać po spawaniu wyżarzaniu homogenizującemu i chłodzeniu w wodzie.

\section{Podsumowanie}

Uzyskanie odporności na korozję wżerową w agresywnym środowisku roztworów chlorków w przypadku połączeń stali duplex spawanych klasycznymi metodami łukowymi wymaga spełnienia kilku czynników o krytycznym znaczeniu:

- staranny dobór materiału rodzimego o możliwie najniższej zawartości pierwiastków ferrytotwórczych, adekwatny do agresywności korozyjnej środowiska; jak najniższa zawartość C i S w wytopie; prawidłowo zbalansowana mikrostruktura w granicach ferryt/austenit $\approx 50 \%{ }^{-10 \%} / 50 \%+10 \%$;

- zastosowanie niskotlenowych metod spawania zwłaszcza do spawania grani i lica spoiny oraz ochrona jeziorka spawalniczego przed absorbcją tlenu z atmosfery;

- zastosowanie dedykowanego materiału dodatkowego o podwyższonej $2 \div 4 \%$ zawartości Ni w stosunku do spawanej stali oraz zapewnienie możliwości wzbogacenia stopiwa o austenitotwórczy azot przez stosowanie gazu formującego i ochronnego o odpowiedniej zawartości $\mathrm{N}_{2}$;

- regulowanie kinetyki przemian fazowych w czasie spawania przez odpowiednie ukształtowanie rowka spawalniczego, kontrolę ilości wprowadzanego ciepła oraz masywności kolejnych ściegów;

- unikanie szkodliwej ekspozycji cieplnej w temperaturze przekraczającej $300{ }^{\circ} \mathrm{C}, \mathrm{w}$ tym przestrzeganie zalecanej temperatury międzyściegowej w czasie spawania i jej ciągły monitoring;

- monitorowanie poziomu zawartości ferrytu $\delta$ w wykonanych złączach;

- chemiczne wytrawianie i pasywacja obszaru spoiny i SWC.

\section{Literatura}

[1] Knyazeva M., Pohl M.: Duplex Steels. Part I: Genesis, Formation, Structure \& Duplex Steels, Part II: Carbides and Nitrides, Metallography, Microstructure and Analysis, 2013, Vol. 2, pp. 113-121 \& pp. 343-351.

[2] Okamoto H., Conf. Proc. Aplications of Stainless Steel 1991, Stockholm, Jernkontoret, 1992, Vol. 1, pp. 360-369.

[3] Hagen M., Bollinger W., Schoffer W.: Sulzer Pumps, Internal Report, 1997 pp. 1-15.

[4] Nilsson J.: Overview - super duplex stainless steels, Journal of Materials Science and Technology, Vol. 8, pp. 685-700, 1992.

[5] Edited by Robert N. Gunn: Duplex stainless steels, Microstructure, properties and applications, Abington Publishing, 1997.

[6] Speidel M.O.: Corrosion Science of Stainless Steels, International Conference on Stainless Steels'91, Chiba Japan, Vol.1, pp. 25-34, 1991.

[7] Holloway G.: Effective Welding of Duplex \& Superduplex Stainless Steels, Singapore Welding Society meeting, Oct. 2003.

[8] Charles J.: Super duplex stainless steels: structure and properties, Proceedings of the Conference on Duplex Stainless Steels '91, Beaune 1991, Vol.1, pp. 3-48

[9] Pohl M., Storz O., Glogowski T.: Effect of intermetallic precipitations on the properties of duplex stainless steel, Materials Characterization, 2007, Vol. 58, pp. 67-71.

[10] http://www.worldstainless.org/Files/issf/non-image-files/PDF/Practical_Guidelines_for_the_Fabrication_of_Duplex_Stainless_Steels.pdf "Practical Guidelines for the Fabrication of Duplex Stainless Steel", 3th edn., International Molybdenum Association (IMOA), London, UK, 2014.

[11] Kotecki D.J.: Ferrite determination in stainless steel welds: advances since 1974, Welding Journal, 76(1), pp. 24-37, 1997.
[12] Souier T., Martin F., Bataillon Ch., Cousty J.: Study of the passive film on duplex stainless steels and its breakdown by AFM and CS-AFM, EUROCORR 2009, Nice, 2009, Vol.5, pp. 2869-2880.

[13] Edited by: I. Alvarez-Armas, S. Degallaix-Moreuil, Duplex Stainless Steels, ISTE Ltd, 2009.

[14] http://www.euroweld.com/uploads/3/0/1/2/30120621/afpm_challenges_welding_duplex_and_super_duplex_stainless_steel_(matt_article).pdf Patrick C.W., Cox M.A.: Challenges Welding Duplex and Super Duplex Stainless Steel, American Fuels \& Petrochemical Manufacturers, 2014 Reliability \& Maintenance Conference, May 2014, San Antonio, Texas, USA.

[15] http://www.gowelding.com/met/duplex.html.

[16] Wiktorowicz R., Crouch J.: Shielding gas developments for TIG welding of duplex and super duplex stainless steels, Welding \& Metal Fabrication, Vol. 62, No. 9, Oct 1994, pp. 379-383.

[17] Messer B., Oprea V., Wright A.: Duplex stainless steel welding: best practices, Stainless Steel World, Dec. 2007.

[18] Babish F.: Repair Welding of Stainless Steels, Sandvik Materials Technology, Presentation Philadelphia, 2014.

[19] Sato Y.S., Kokawa H., Kuwana T.: Effect of nitrogen on sigma transformation in duplex stainless steel weld metal, Science and Technology of Welding and Joining, 1999, Vol. 41.

[20] Amelie Fanica: Duplex Stainless Steel Welding, Dubai, February 2008.

[21] L. van Nassau, Meelker H., Neessen F., Hilkes J.: Welding duplex and superduplex stainless steel. An update of the guide for industry; http:// www.lasgroepzuid.com/documenten/Update_guide_Welding_duplex_ and_superduplex_stainless_steel.pdf.

[22] Ward I.: Report on weld cleaning methods, Document IW 150807, Sandvik Australia Pty Ltd, 2007. 